\title{
Banking Efficiency in Kosovo during the Global Financial Crisis
}

\author{
Jeton Zogjani, MSc
}

zogjanijeton@gmail.com

\author{
Malësor Kelmendi, MSc
}

malsor_kelmendi@hotmail.com

\section{Doi:10.5901/ajis.2015.v4n2p367}

\begin{abstract}
In this research paper is analyzed the impact of banking efficiency on banking sector during of global financial crisis 2008 2010 with special focus Kosovo and as the main arguments for discussions are as following: overall banking efficiency in Kosovo, difference between loan and deposit rates in banking sector and difference in efficiency among banks with domestic and foreign investment. In methodology, the data collections are from financial and banking institutions in Kosovo and they are used and calculated through STATA program. The two main analyses are: DEA model (CRS and CRS model for efficiency) and regression methods (OLS method of regression and correlation matrix). The result of DEA analysis indicate that there is a constant increase of efficiency from 0.795 (CRS \& VRS) in 2008 to 0.832 (CRS) and 0.913 (VRS) in 2010. The OLS method shows results as following: all variables that are involved in the research (non - performing loans -9.9, interest rate of loans -5.2 and $R O A$-14.7) have negative impact on banking sector. Also in T-statistics analysis argue that all variables are non-significant $(T<2)$ to banking sector. In correlation method, the results show that the non - performing loans $(-0.48)$ and ROA $(-0.08)$ have a negative correlation whereas FDI (0.06) has positive correlation to banking sector.
\end{abstract}

Keywords: DEA analysis, interest rate, loan and deposit, ROA, STATA analysis

\section{Introduction}

In this part of paper research will be oriented in the banking efficiency in Kosovo. To create a favorable banking environment for countries in transition, some essential requirements must be fulfilled, such as: macroeconomic and political stability, structural reforms and the creation of some new regulatory frameworks across the region have been crucial for the banking sector in the recent years (Backé, P \& Walko, Z 2006). As commented (Fang et al 2011) the development of institutional reform, defining ownership and privatization, the market structure and its competitors, and the conversion of corporate governance from the previous system have been indispensable to increase banking efficiency for all the countries in transition, including Kosovo. The Kosovo started the process of creating a banking system just after the war ended, this process was accomplished through the help of the international financial institutions such as IMF, WB, and USAID, etc. According to CBK Report (2011), the Central Bank of Kosovo (CBK) was established in the 2000, with the main purpose of creating a new paying system among banks in Kosovo. In Kosvo the banking system was the least efficient from 2002 till 2005 if compare with the banking systems in neighbouring countries, although efficiency improvement can taken time to achieve same level that have countries in region. The banking sector in Kosovo is very specific and complex area to research, thus (Lumir Abdixhiku \& Uk Lushi 2011) argues that the banking system is experiencing an expansionary and stable cycle, which is justified by the responsibility of the state institutions and the clients behavior on one side and the high difference between the loan and deposit rates including the low level of bad debt on the other side. The measurement of performance on the banking activity is done through this indicator, efficiency refers to a process where we produce more outputs (products or services) with the same amount of inputs.

\section{Literarure Review}

In this part of the paper research will discussed different matters in the banking sector of Kosovo. Then banking sector always is considering as a very difficult service industry to understand, to manage and to measure, like their output, technical change and their productivity growth (Berger \& Humphrey 1990). if analyze the structure of capital owned in banking sectors in the most of SEE countries, we can find that foreign-owned banks have a larger share of total assets in 
overall banking sector in these countries also these banks are associated with lower costs to banks with domestic ownership and more efficient than state-owned banks in overall financial and banking market (Fries \& Taci 2005). According to IMF Report (2013), the banking sector in Kosovo is dominated by foreign banks but majority of funded deposits are domestic. Then in this part of paper will discuss different arear of banking effiency in Kosovo, such as: overall banking efficiency in Kosovo; difference between loan and deposit rates; dfference in efficiency among banks with domestic and foreign investment.

\subsection{Overall banking efficiency in Kosovo}

The financial sector and its stability have a crucial importance in the economy whereas the banks play an important role in some countries. In 2003, in 9 countries of South-Eastern Europe banking activities composited about 70\% of the GDP and now this sector has a higher potential (Stavárek 2006). According to IMF Report (2013) during the global crisis of 2008 - 2009 in banking sector in the Western Balkan are financed their capital in banking sector by foreign funding and it has brought a boom in credit sector and in Kosovo banking sector has fast growth rate of private credit and deposits over the last decade. Kosovo's banking system is composed of two levels: the first is the CBK 2011 as the only financial and banking institution which monitors, regulates and controls the banking system in Kosovo and the second are the commercial banks. According to (CBK 2011) there is 8 banks, most of banking market is made of foreign capital (90.2 \%), whereas there are only $9.8 \%$ for domestic capital in the banking system (for more detail see table below).

Table 1. The Banking Structure in Kosovo

\begin{tabular}{|l|c|c|c|}
\hline The commercial banks in Kosovo & Market share & Capital Ownership & Entry the Market \\
\hline ProCredit Bank Kosovo & $30.8 \%$ & Foreign & 2000 \\
\hline Raiffeisen Bank Kosovo & $27.0 \%$ & Foreign & 2003 \\
\hline NLB Prishtina & $15.6 \%$ & Foreign & 2008 \\
\hline TEB Bank & $8.5 \%$ & Foreign & 2008 \\
\hline Economic Bank & $6.0 \%$ & Domestic & 2001 \\
\hline Banka for Business & $5.0 \%$ & Domestic & 2001 \\
\hline National Trade Bank - Kosovo Branch & $5.4 \%$ & Foreign & 2007 \\
\hline
\end{tabular}

Source: CBK Annual Report 2011 \& the Kosovo Authority Competition Report (KAC) 2011

If we analyze other indicators in the banking sector, among which we will understand the stability and efficiency level in Kosovo, we will arrive to the conclusion that in 2009 the banking sector had almost $18.0 \%$ of capital sufficiency with a $12.0 \%$ minimum. Between 2006 - 2009 there is an average of 3.4\% appeared from the bad loans report with loan problems (Maloku 2012). According to CBK Report (2010), CBK Report (2011) and KAC Report (2011) is identified different factors that influenced the continuous growth and these factors are: a) A stable macroeconomic environment; b) Safe and effective supervision by $\mathrm{CBK}$; c) A transparent, competitive and functional banking market; d) investment in securities, etc. If refer to CBK Report (2011) on the development indicators of banking efficiency from 2008 - 2011, we will see different financial statements (see table 2) like total assets ratio to the number of employees, with a yearly average increase in $15 \%$ or the ratio of the average number of loans and the number of employees with a yearly average increase of $10.5 \%$. These ratios show us that there is an increasing positive trend in banking efficiency. This is justified by the continuous growth of credit in the banking market despite of the growth in the number of employees in this sector. This is reflected even in the rapid growth of assets. Rapid trend movements, may they be positive or negative, have been noticed in the profit ratio to the number of employees, the net interest margin ratio has consistently tended to decrease:

Table 2. Indications of banking efficiency in Kosovo 2008 - 2011 (in thousand €):

\begin{tabular}{|l|c|c|c|c|}
\hline Describe of Indicators & $\mathbf{2 0 0 8}$ & $\mathbf{2 0 0 9}$ & $\mathbf{2 0 1 0}$ & $\mathbf{2 0 1 1}$ \\
\hline Assets / No of employees & 467.6 & 503.6 & 637.9 & 684.4 \\
\hline Profit / No of employees & 6.9 & 3.2 & 5.4 & 4.1 \\
\hline No of credit / No of employees & 68.8 & 66.6 & 75.8 & 92.3 \\
\hline Net Interest Margin & 4.1 & 3.4 & 3.0 & 2.6 \\
\hline
\end{tabular}

Source: CBK Annual Reports 2010 \& 2011 


\subsection{Difference between loan and deposit rates}

The lack of banking efficiency is caused by the uncertainty in the banking market in Kosovo, macroeconomic and political stability. All of the above mentioned reasons have caused the banking efficiency to decrease. When we compare loans in Kosovo from 2001 - 2007, they reach 20\% - 24\% of GDP meanwhile other countries reach 75\% of banking loans to the GDP and developed countries reach a loan rate of $160 \%$ of GDP. To have a higher and more stable banking efficiency, the loan and deposit rates difference must get tighten. According to RIInvest Report (2012), the main factors that impact in changing in the banking efficiency are: increased competition in the banking sector; increased financial opportunities, a more efficient juridical system, lack of cadastral and property definition. Kosovo was the return of short-term and high rates of loans and this has been one of the major obstacles for a high efficiency in the banking sector but also for other economic sectors. If we review these past year's reports on loan and deposit rates, we will notice that in 2009 there is an increase in deposits and an increase in deposits causes the banking efficiency to increase as well (Maloku 2012). In table below is appear the interest rate performances and level of deposits from 2004 - 2011:

Table 3. Difference between interest rates on loan and deposits (\%)

\begin{tabular}{|c|c|c|c|c|c|c|c|c|}
\hline & $\mathbf{2 0 0 4}$ & $\mathbf{2 0 0 5}$ & $\mathbf{2 0 0 6}$ & $\mathbf{2 0 0 7}$ & $\mathbf{2 0 0 8}$ & $\mathbf{2 0 0 9}$ & $\mathbf{2 0 1 0}$ & $\mathbf{2 0 1 1}$ \\
\hline Loans & 14.2 & 14.2 & 13.4 & 14.6 & 14.8 & 14.4 & 14.4 & 14.3 \\
\hline Deposit & 2.5 & 3.2 & 3.0 & 3.3 & 4.2 & 4.3 & 3.7 & 3.5 \\
\hline Difference rate (C=A-B) & 11.7 & 11.0 & 10.4 & 11.3 & 10.6 & 10.1 & 10.9 & 10.8 \\
\hline
\end{tabular}

Source: CBK Annual Reports 2004 \& 2011

\subsection{Difference in efficiency among banks with domestic and foreign investment:}

Different authors have emphasized that the entrance of foreign capital banks in the market has caused a reduction of profitability, high operating costs and lower loaning performance so the banking structure capital between them is high (Bonin et al 2005). In the Czech Republic in 2001 foreign capital banks were 70\% of banking market (Weill 2003). In Bulgaria after 2007 more than $80 \%$ of banking capital was foreign and $98 \%$ of this sector was the private property (Nenovsky 2010). Structure changes in countries that have a higher control on the banking sector, so in Russia where banks have to operate in different institutional environments like public and private banks, where public banks have greater access to less costly deposits, physical capital, labor, etc. It is the reason that banks have obvious advantages in banking efficiency (Karas et al 2008). The fast growing dynamics in the competitive banking market have forced banks to increase their competitiveness. With the establishment of the banking sector in Kosovo, there was an immediate penetration of foreign capital banks. These banks play a major role considering that they constitute $90 \%$ of the banks in this market, whereas domestic banks only $10 \%$. The main reason is that these banks are more experienced than the domestic ones, the table below shows the capital structure the foreign and domestic banks:

Table 4. Relationship between Domestic \& Foreign Capital in the Banking Sector in 2011 (\%)

\begin{tabular}{|c|c|c|c|c|c|c|c|c|}
\hline Banks & Procredit Bank & Raiffeisen Bank & NLB Bank & TEB Bank & Economic Bank & BpB Bank & BKT Bank & Market Share \\
\hline Foreign & 100.0 & 100.0 & 81.58 & 100 & 0.0 & 5.0 & 100. & 90.2 \\
\hline Domestic & 0.0 & 0.0 & 18.48 & 0.0 & 100.0 & 95.0 & 0.0 & 9.8 \\
\hline
\end{tabular}

Source: CBK Annual Report 2011 \& Kosovo Competition Authority (2011)

\section{Methodology and Data Collection}

In the methodology part I will discuss on the principles of the paper research: how are data collected and analyzed? how these data has impact on Banking Efficiency in Kosovo during the Global Crisis? The data used in this paper research are secondary data and they are collected in period time between 2007 - 2011 by official financial and banking institutions in Kosovo (CBK and annual reports of commercial banks in Kosovo). All data that were used in this paper research are calculated through econometric program STATA and the data are analyzed through two main analysis: A) the first 
analysis is DEA approach (CRS and VRS models), it is a mathematical and statistical method that analyzes the efficiency of banks in their success through their banking inputs and outputs (Jemri, I. \& Vujecic, B. 2002). The main variables that are used in DEA approach are as following: a) total assets of the banks and the number of employees in the banking sector, they are defined as inputs variables; $b$ ) the level of loans that banks provide as the main product and the level of bank profits that banks perform along with their banking activities, they are as output variables. B) the second analysis are different regression methods (OLS method and Correlation method) and these methods are used to find the relationship between the variables that are used, where as the dependent variables is the annual rate of banking sector and as the independent variables are the following: non - performing loans, interest rate of loans and ROA. Econometric model was used for data analysis of regression analysis with the following formula: $\operatorname{Ln}(B S t)=\beta 0+\beta 1 \ln (N P L t)+\beta 2 \ln$ $(I R L t)+\beta 3 \ln (R O A t)+\varepsilon t$. The main variables are as follows:

- $\mathrm{BS}=$ Banking Sector;

- $N P L=$ Non - Performing Loans;

- $\quad \mathrm{RR}=$ Interest Rate of Loans;

- ROA = Return of Assets;

- $\varepsilon \mathrm{t}=$ Standard Error;

- $\beta 0, \beta 1, \beta 2, \beta 3$, are included in the analysis parameters;

\section{Emprical Results and Interpretations}

In this part of paper research is presented the results achieved through two main analyses: DEA analysis and regression analysis. The main results are realized by STATA program (econometric software for data calculates). In fact, his constitutes the most important part because here will interpret the implications of the parameters that are involved in research paper.

\subsection{Results of DEA analysis:}

As part of the paper research is DEA model, more specifically the use of CRS and VRS models to analyze the banking efficiency in Kosovo so the CRS model (Constant Return-to-Scale), relies on supposing the increase of outputs from the same amount of inputs used in the banking activity, and the VRS model (Variable Return-to-Scale) represents the level of inputs in relation to the level of change of outputs in the banking activity, by (Podinovski 2004). If we rely on the results calculated by the two models of DEA involved in the research (see table 5), we understand that there is a steadily increasing average efficiency in the banking sector as a whole, from 0795 (according to CRS \& VRS model) in 2008 increased to 0.832 (CRS) 0.913 respectively (CRS) in 2010. This increase in efficiency over this period is justified by the increase in loans (together with securities) amounted to 11.4\% annual growth in 2010 in all sectors, both of them (loans and securities) comprise the biggest part of assets in the banking sector over 65\%. Only in 2010 the annual growth of total assets in commercial banks has reached over 250 million euros. The year 2009 marks a decrease of average banking efficiency, due to the decrease in the number of employees in this sector by $5 \%$ and increased spending for banking infrastructure (Point of Sale - POS, ATMs, e-banking, etc.) but it gives positive results in 2010 with an increase in both models (CRS \& VRS) of the DEA model.

Regarding the banking efficiency between foreign banks and local banks, there is a completely opposite performance of efficiency among domestic and foreign capital banks. Foreign capital banks had a high level of efficiency in 2008 according to CRS \& VRS models. This happened because of stability and continuous entrance of foreign banks in the market (TEB Bank in 2008), while in 2008 was characterized with a strong consolidation of domestic capital banks after their lack of stability (failure of CBP Bank in 2006) thus the average efficiency for these banks was 0.48 . All this resulted in a high level of difficulty regarding achieving efficiency (0.52) between domestic and foreign capital banks. Also, if we take into consideration the standard deviation in 2008 we will realize that exist the highest values of this indicator (0.48), which in fact means that there is a wider spread between the general banking efficiency in foreign banks compared to the local ones. 
Table 5. The DEA efficiency scores in banking sector in Kosovo (CRS \& VRS Model)

\begin{tabular}{|l|c|c|c|c|c|c|}
\hline & \multicolumn{3}{|c|}{ CRS Model } & \multicolumn{3}{c|}{ VRS Model } \\
\hline & 2008 & 2009 & 2010 & 2008 & 2009 & 2010 \\
\hline Number of Banks (Foreign \& Domestic) & $8(2)$ & $8(2)$ & $8(2)$ & $8(2)$ & $8(2)$ & $8(2)$ \\
\hline Average efficiency in Banking sector & 0.795 & 0.740 & 0.832 & 0.795 & 0.743 & 0.913 \\
\hline Ranging efficiency per years & 2 & 3 & 1 & 2 & 3 & 1 \\
\hline Average efficiency of foreign banks & 1 & 0.88 & 0.76 & 1 & 0.88 & 0.88 \\
\hline Average efficiency of domestic banks & 0.48 & 0.46 & 1 & 0.48 & 0.47 & 1 \\
\hline Efficiency Gap [Foreign - Domestics] & 0.52 & 0.42 & -0.23 & 0.52 & 0.41 & -0.12 \\
\hline Standard deviation & 0.48 & 0.43 & 0.33 & 0.48 & 0.44 & 0.20 \\
\hline Scale inefficiency [1 - (CRS / VRS)] & - & - & - & 0.000 & 0.004 & 0.088 \\
\hline
\end{tabular}

\section{Source: Calculated by authors}

Regarding average banking efficiency, there was a slight decrease from 0.740 and 0.743 (according to CRS \& VRS) in 2009 to 0.795 and 0.795 in 2008 . This happened because the decrease in the total number of employees and the number of (sub-) branches of all banks. This year was characterized by the decrease of operative expenses and the decrease of the level of loans with an average yearly rate of $9.0 \%$ compared to $32.7 \%$ in 2008 . It is worth mentioning the decrease of the difference between the average efficiency of foreign banks compared to the domestic ones. This was achieved as a result of the continuous increase of banking services from the smaller banks in banking sector, thus this is all reflected in the decrease of standard deviation (0.43 and 0.44 in 2009), which shows that the averages of these two types of banks are getting closer and the decrease of the gap between them.

Year 2010 constitutes the highest level of the banking efficiency with 0.832 respectively 0.913 (CRS and VRS). One of the factors that have affected the increase of efficiency is a more stable financial global market and this was also reflected in Kosovo through two elements which directly increased the average. The first is represented through the increase of loan requests and the second is the decrease of "obligated" reserves that commercial banks used to have to CBK. So, what characterizes the banking efficiency this year is the positive increase of $1.3 \%$ in the level of domestic capital banks where there participation was approximately $10 \%$, foreign capital banks constitute $90 \%$ of the market. This was confirmed by indicators of average efficiency of these banks and the efficiency gap involved in the research. Survey data reflects a high degree of efficiency for local banks to those with foreign capital, all this because of the growth of the local banking activities of banks in the banking market. Then the standard deviation indicator (0.33 and 0.20) of 2010 shows a significant alignment between the average efficiency of foreign banks and local ones.

If we refer to the above table in the indicator of non-efficiency where is reflected a low level with the tendency to grow, we see that this comes as a result of high interest rates of commercial banks in Kosovo during the years of the research. The banks justify this high rate of interest, because the shapes of the threat posed by the banking market, such as: a) Credit risk - it constitutes the main concerns that banks in Kosovo have due to credit risk on loans given to their customers; b) liquidity risk - this is the rate of cash adequacy that banks must have to market demand; c) market risk this is based mainly on sustainability and interest rate sensitivity d) operational risk - involves adapting the banking technology to competitors and bank management operational activities.

\subsection{Results of regression analysis}

In the table 6 is presented the OLS method that show the level of positive / negative impact that non-performing loans, interest rate of loans and ROA have as independent variables in banking sector as the dependent variable. Considering the other variables are unchanged (or constant) and an increase of non-performing loans for a unit, will affect the banking sector rate by -9.9 (negative impact), as well as an interest rate of loans for a unit, when the other variables remain constant, it will have effect on banking sector by -5.2 (negative impact). Also increasing the ROA rate for a unit will affect in banking sector in a same way, by -14.7 (negative impact). Through T-Statistics, we will understand the explanatory of significance between depend and independents variables, so T-Statistic can be positive $(T>2)$ or negative $(T<2)$, of independent variables on the dependent ones. Based on t-statistic results, all variables (Non-performing Loans -2.43 , Interest rate of Loans -0.43 and ROA -2.07 ) that are included in analysis have showed no significant explanatory ability $(\mathrm{T}<2)$ on banking sector. 
Table 6. Ordinary Least Squares (OLS) Method

\begin{tabular}{|l|c|c|c|c|c|}
\hline & Coefficient & Std. Error & $\mathbf{t}$ & $\mathbf{P}>|\mathbf{t}|$ & $\mathbf{R}^{\mathbf{2}}$ \\
\hline Constant & 162.9 & 178.3 & 0.91 & 0.53 & 0.85 \\
\hline Non-performing Loans & -9.9 & 4.1 & -2.43 & 0.25 & \\
\hline Interest rate of Loans & -5.2 & 11.9 & -0.43 & 0.74 & \\
\hline ROA & -14.7 & 7.1 & -2.07 & 0.28 & \\
\hline
\end{tabular}

Source: Authors

If we analyze the $\mathrm{R}^{2}$ indicator (which is known as coefficient of determination) in table 2, it tells us the scope of the relationship between independent variables and the dependent variables. According to the results that we achieve in OLS method, these independent variables (Non-performing Loans, Interest rate of Loans and ROA) have a relationship of nearly $85 \%$ with dependent variables (banking sector) and $14 \%(100 \%$ - $86 \%)$ with other factors that are not included in this methods. In Table 7, if we analyze the independent variables to the dependent variable, based on the level of correlation method (or sensitivity), is found that the non-performing loans and ROA have negative correlation by -0.48 and -0.08 to banking sector. It means that a change of banking sector by $1 \%$, will associated with decreasing of nonperforming loans by $-0.48 \%$ and ROA -0.08 . Only interest rate of loans has a positive correlation (sensitive effect) to banking sector, so one possible change in banking sector have "obvious" effect on interest rate of loans.

Table 7. Correlation Method

\begin{tabular}{|l|c|c|c|c|}
\hline & Banking Sector & Non-perfor. Loans & Interest rate (Loans) & ROA \\
\hline Banking Sector & 1.00 & & & \\
\hline Non-performing Loans & -0.48 & 1.00 & & \\
\hline Interest rate of Loans & 0.06 & 0.09 & 1.00 & \\
\hline ROA & -0.08 & -0.80 & -0.27 & 1.00 \\
\hline
\end{tabular}

Source: Authors

\section{Conclusion}

Different political and economic processes that Kosovo has gone last 20 years, the banking sector has been shocked from these changes of transition process. Now the financial institution is controlled and monitored by CBK so banking sector during period of time 2008 - 2010, have included 8 commercial banks, out of which 6 have foreign capital and 2 domestic capitals then the structure of capital is the foreign banks have $90.2 \%$ of banking assets while domestic capital banks only $9.8 \%$. The most important issue in this paper research is banking efficiency by DEA analysis (CRS \& VRS models) and as main inputs in this analysis are: total assets and the number of employees and as main outpusts are defined the level of loans and the level of bank profits. The result of DEA analysis indicate that there is a constant increase of efficiency from 0.795 (CRS \& VRS) in 2008 to 0.832 (CRS) and 0.913 (VRS) in 2010. As a main factor that has influenced the increase of efficiency are loans given by banks, which only in 2010 increased by $11.4 \%$, the role of these loans in total assets of the banks is major (65\%). During this period the banking sector was characterized by a decrease of the number of employees and the improvement of infrastructure and banking technology.

In this paper of research is presented conclusion on banking efficiency in Kosovo during the financial global crisis. The data used in this paper of research are secondary data and cover a period of time between 2008 and 2010. The main variables are: banking sector (as a depend variable), non-performing loans, interest rate of loans and ROA (as independent variables). Empirical Results are made by STATA program and the main analyses are made by: Ordinary Least Squares (OLS) method and Correlation method. The OLS method shows results as following: all variables that are involved in the research (non - performing loans -9.9, interest rate of loans -5.2 and ROA -14.7) have negative impact on banking sektor. Also in T-statistics analysis argue that all variables are non-significant $(T<2)$ to banking sektor. The $\mathrm{R}^{2}$ analysis, measures the relationship of the independent variables with the dependent ones and it is $85 \%$, whereas $15 \%$ are other factors related to the dependent variable that are not included in this research. In correlation method, the results show that the non - performing loans $(-0.48)$ and ROA $(-0.08)$ have a negative correlation to banking sector whereas FDI 
(0.06) has positive correlation to banking sector.

\section{References}

Karas et al (2008). Are private banks more efficient than public banks? Evidence from Russia. Bank of Finland: Institute for Economies in Transition, BOFIT Discussion Papers 3, pp. 1 - 16

Backé, P \& Walko, Z. (2006). Bank Intermediation in Southeastern Europe: Depth and Structure. Focus on European Economic Intigration, pp. 48 - 68.

Phelps et al (2003). International Banking Strategy and Efficiency: issues and directions. 7th International Conference of the Decision Sciences Institute. Shanghai, 4 July, 2003. pp. 1 - 6

CBK Report (2010). Financial Stability Report No.1. Department of Financial Stability and Economic Analysis, 19. [Report] Pristine: December 2010, pp. 1 - 121.

CBK Report (2011). Financial Stability Report No 2. Department of Financial Stability and Economic Analysis [Raport], Prishtine, pp. 1 130.

CBK Report (2010). Interbank Payment Systems: History [Online]. Payment System Report, Prishtina: Central Bank of Kosovo.

Govori, G. (2009). The Banking System in Kosovo and its Role in Economic Development. MPRA Paper (Munich Personal RePEc Archive), No. 24536, pp. 1 - 5.

IMF Report (2013). Republic of Kosovo 2013 Article IV Consultation. IMF Country Report No. 223, [Online], IMF: Publication Services, Washington D.C. pp. 1 - 27.

Jemri, I. \& Vujecic, B. (2002). Efficiency of Banks in Croatia. Working Papers: Public Relations and Publishing Department, ISSN 13318586, Zagreb: Croatian National Bank, pp. 1 - 32.

Bonin, J. \& Wachte, P. (2005). Privatization matters: Bank efficiency in transition countries. Journal of Banking \& Finance, 29 (8 - 9), 2005: pp. 2155 - 2178.

KAC Report (2011). Analysis of Monitoring in the Banking Sector in Kosovo. [Report] Pristine. The Kosovo Competition Authority (Perodical Government Report), 13, pp. 1 - 20.

Abdixhiku, L. \& Lushi, U. (2011). Koha per ndryshimin e Bankave. Koha Ditore (Deal newspaper), 29. April 2011

Maloku, E. (2012). Role of Central Bank in the Establishment and the Development of Financial System in Post-War Kosovo. Journal of Knowledge Management, Economics and Information Technology (5), pp. 1 - 20.

Mark et al (2009). Research Method for Business Students. 5th ed. England: Pearson Education Ltd.

Mullineaux, D.J. (1978). Economies of Scale and Organizational Efficiency in Banking: A Profit- Function Approach. The journal of Finance, 32 (1), pp. 1 - 23.

Tochkov, K. \& Nenovsky, N. (2010). Institutional reforms, EU accession, and bank efficiency in transition economies: Evidence from Bulgaria." South University Drive, Texas, USA: Texas Christian University, Working Paper No. 10 - 02, pp. 1 - 32.

Toci, V. (2009). Efficiency of Banks in South-East Europe: With Special Reference to Kosovo. CKB -Working Paper, No 4. Office of the Chief Economist Publication, pp. 36

Podinovski, V.V. (2004). Bridging the gap between the constant and variable returns-to-scale model: selective proportionality in data envelopment analysis. The Journal of the Operational Research Society, 55, pp. 265 - 576.

RIInvest Institute. (2012). Banking Sector: Facilitation or Barrier. [Report] Pristine. Raport by Forum 2015, Prishtinë: RIInvest Institute.

Milind. S. (2003). Privatization, Performance, and Efficiency: A Study of Indian Banks. World Bank Conference, October 2003, 30 (1). pp. 1 - 10, World Bank Conference on Bank Privatization, Performance and Efficiency. India: Indian Institute of Management, pp. 1 10.

Daniel, S. (2006). Banking Efficiency in the Context of European Integration." Eastern European Economics, 44 (4), pp. 5 - 31.

Weill, L. (2003). Banking efficiency in transition economies: The role of foreign ownership." The Economics of Transition, 11 (3), pp. 569 $-592$.

Fang et al (2011). Bank efficiency in transition economies: recent evidence from South-Eastern Europe. Bank of Finland Research Discussion Paper No. 5, pp. 1 - 41.

\section{Appendixes}

Appendix 1/A

Table 1/A. Data descriptions for analysis the DEA analysis (2008)

\begin{tabular}{|l|c|c|c|c|c|}
\hline Banking Efficiency 2008 & Assets & Employees & & Loans & Profit \\
\hline ProCredit Bank & 642439 & 1158 & & 424567 & 19027 \\
\hline Raiffeisen Bank & 601077 & 723 & & 413091 & 15308 \\
\hline NLB Bank & N / A & N/A & & N/A & N/A \\
\hline TEB Bank & N/A & N/A & & N/A & N/A \\
\hline Ekonomic Bank & 86117 & 267 & & 53331 & 1014 \\
\hline Bank for Business & 61179 & 299 & & 34289 & 1824 \\
\hline National Commercial Bank & 17901 & 104 & & 9701 & 701 \\
\hline
\end{tabular}

Source: Annual reports of commercial banks in Kosovo 2008 


\section{Appendix 1/B}

Table 1/B. Data descriptions for analysis the DEA analysis (2009)

\begin{tabular}{|l|c|c|c|c|c|}
\hline Banking Efficiency 2009 & Assets & Employees & & Loans & Profit \\
\hline ProCredit Bank & 732.506 & 1177 & & 453.566 & 21.376 \\
\hline Raiffeisen Bank & 682.358 & 666 & & 357.355 & 7.029 \\
\hline NLB Bank & 386.913 & 698 & & 128.531 & 5.162 \\
\hline TEB Bank & $\mathrm{N} / \mathrm{A}$ & $\mathrm{N} / \mathrm{A}$ & & $\mathrm{N} / \mathrm{A}$ & $\mathrm{N} / \mathrm{A}$ \\
\hline Economic Bank & 86.117 & 267 & & 5.211 & 1.014 \\
\hline Bank for Business & 87.086 & 316 & & 48.344 & 511 \\
\hline National Commercial Bank & 56.901 & 129 & & 38.201 & 701 \\
\hline
\end{tabular}

Source: Annual reports of commercial banks in Kosovo 2009

\section{Appendix 1/C}

Table 1/C. Data descriptions for analysis the DEA analysis (2010)

\begin{tabular}{|l|c|c|c|c|c|}
\hline Banking Efficiency 2010 & Assets & Employees & & Loans & Profit \\
\hline ProCredit Bank & 783.305 & 1108 & & 476.437 & 22.371 \\
\hline Raiffeisen Bank & 679.161 & 684 & & 391.926 & 10.177 \\
\hline NLB Bank & 351.355 & 769 & & 209.001 & 5.206 \\
\hline TEB Bank & 212.553 & 379 & & 15.817 & 2.363 \\
\hline Economic Bank & 98.686 & 272 & & 7.564 & 671 \\
\hline Bank for Busniess & 103.315 & 345 & & 65.663 & 702 \\
\hline National Commercial Bank & 91.001 & 171 & & 67.901 & 1.001 \\
\hline
\end{tabular}

Source: Annual reports of commercial banks in Kosovo 2010

\section{Appendix 2/A}

Table 2/A. Data descriptions for analysis the regression methods (percentage \%)

\begin{tabular}{|l|c|c|c|c|c|}
\hline & $\mathbf{2 0 0 7}$ & $\mathbf{2 0 0 8}$ & $\mathbf{2 0 0 9}$ & $\mathbf{2 0 1 0}$ & $\mathbf{2 0 1 1}$ \\
\hline Banking Sector & 7.0 & 20.2 & 24.1 & 13.7 & 9.3 \\
\hline Non - performing of Loans & 4.1 & 2.8 & 4.3 & 5.2 & 5.8 \\
\hline Interest Rate of Loans & 14.1 & 13.8 & 14.1 & 14.3 & 13.7 \\
\hline ROA & 2.6 & 3.1 & 1.5 & 1.8 & 1.7 \\
\hline
\end{tabular}

Source: CBK Financial Stability Report 2008 \& 2011

\section{Appendix 3/A}

Table 3/A. Variable Descriptions and Sources for DEA analysis

\begin{tabular}{|l|l|l|}
\hline Variable & Description & Source \\
\hline Total assets & $\begin{array}{l}\text { The total assets of banks include: cash, loan advance for banks and customers, intangible assets, } \\
\text { property and equipment, other financial assets }\end{array}$ & $\begin{array}{l}\text { ProCredit Bank - Annual Report } \\
2013\end{array}$ \\
\hline The number of Employees & $\begin{array}{l}\text { They are employees of a bank who deals directly with customers for all banking services (income from } \\
\text { service) }\end{array}$ & $\begin{array}{l}\text { Raiffeisen Bank - Annual Report } \\
2013\end{array}$ \\
\hline The level of Loans & $\begin{array}{l}\text { Loans and advances to customers include accrued interest income, deferred disbursement fee from } \\
\text { loans to customers }\end{array}$ & NLB Bank - Annual Report 2013 \\
\hline The level of Profit & $\begin{array}{l}\text { Net profit margin is the percentage of remaining after all operating expenses, interest, taxes have been } \\
\text { deducted from a company's total revenue }\end{array}$ & $\begin{array}{l}\text { Bank for Business - } \\
\text { Annual Report 2013 }\end{array}$ \\
\hline
\end{tabular}

Source: Authors

Appendix 3/B

Table 3/B. Variable Descriptions and Sources for Regression methods

\begin{tabular}{|l|l|l|}
\hline Variable & Description & Source \\
\hline Annual Banking Sector Rate & $\begin{array}{l}\text { The annual rate of banking sector represents an annual growth of capital (\%) as in domestic and } \\
\text { foreign banks }\end{array}$ & CBK - Annual Report 2014 \\
\hline Non - performing of Loans & $\begin{array}{l}\text { A non-performing loan is in default (non-returnable) and in 2014 the rate of NLP in Kosovo is 8.2\% } \\
\text { in 2014 }\end{array}$ & CBK - Annual Report 2014 \\
\hline Interest Rate of Loans & $\begin{array}{l}\text { The interest rate on the loan actually transferred from borrowers, which simultaneously reflect } \\
\text { revenues from the operation of lending banks }\end{array}$ & $\begin{array}{l}\text { CBK - Financial Stability Report } \\
2012\end{array}$ \\
\hline ROA & $\begin{array}{l}\text { Return on Assets - it is an indicator that present how profitable a company is relative to its total } \\
\text { assets }\end{array}$ & $\begin{array}{l}\text { CBK - Financial Stability Report } \\
\text { 2012 }\end{array}$ \\
\hline
\end{tabular}

Source: Authors 